\title{
Effect of Genetic and Non-Genetic Factors on First Lactation Production and Reproduction Traits in HF × Gir Cattle
}

\author{
S.S. Jadhav ${ }^{\text {* }}$, D.K. Deokar ${ }^{2}$, Y.G. Fulpagare ${ }^{3}$, U.Y. Bhoite ${ }^{4}$, \\ S.D. Mandkmale ${ }^{5}$ and C.V. Nimbalker ${ }^{6}$ \\ ${ }^{1}$ RCSM College of Agriculture, Kolhapur, India \\ ${ }^{2}$ College of Agriculture, Dhule, India \\ ${ }^{3}$ Department of Animal Husbandry and Dairy Science, Mahatma Phule Krishi Vidyapeeth, \\ Rahuri, India \\ ${ }^{4}$ Research cum Development Project on Cattle, Mahatma Phule Krishi Vidyapeeth, \\ Rahuri, India \\ ${ }^{5}$ AICRP on Goat, Mahatma Phule Krishi Vidyapeeth, Rahuri, India \\ ${ }^{6}$ Department of Statistics, Mahatma Phule Krishi Vidyapeeth, Rahuri, India \\ *Corresponding author
}

\begin{tabular}{|l|}
\hline Ke y w o r d s \\
HF $\times$ Gir cattle, \\
Genetic parameter, \\
First lactation traits \\
\hline Article Info \\
\hline $\begin{array}{l}\text { Accepted: } \\
\text { 04 December } 2018 \\
\text { Available Online: } \\
\text { 10 January } 2019\end{array}$ \\
\hline \hline
\end{tabular}

A B S T R A C T

The present investigation was carried out with the objective of performance appraisal of $\mathrm{HF} \times$ Gir cattle with respect to production and reproduction traits. The performance records of $421 \mathrm{HF} \times$ Gir half breed cattle sired by 48 bulls were collected for production and reproduction traits spread over a period of 39 years (1977 to 2015) from ResearchCum Development Project on Cattle, Mahatma Phule Krishi Vidyapeeth, Rahuri District Ahmednagar (Maharashtra). The overall least squares means for first lactation total milk yield (FLTMY), first lactation 300 days milk yield, first lactation length (FLL), First dry period (FDP), First service period (FSP), First calving interval (FCI) and Age at first calving were $2701.77 \pm 46.04,2511.70 \pm 37.40,320.43 \pm 3.04,88.40 \pm 2.58,130.14 \pm 3.19$, $409.17 \pm 3.25$ and $990.69 \pm 6.53$ days, respectively. Further, the least squares analysis revealed non significant effect of season of calving and age at first calving groups on all first lactation reproduction and milk production traits. Whereas, the effect of period of calving was found to be highly significant on FLTMY, FL300DMY and AFC and nonsignificant on FLL, FDP, FSP and FCI. However, the effect of sire was found to be significant on FLTMY, FL300DMY and AFC. The heritability of all traits except FCI and FSP were moderate in magnitude which indicated these traits are more influenced by additive genetic variability and hence there is more scope for improvement by selection. The highly significant genetic and phenotypic correlation was found between production and reproduction traits. 


\section{Introduction}

Livestock sector is an important subsector of the agriculture of Indian economy. It forms an important livelihood activity for most of the farmers, supporting agriculture in the form of critical inputs, contribute into the health and nutrition of the household, supplementing income, offering employment opportunities, and finally being a dependable "bank on hooves" in times of need. It acts as a supplementary and complementary enterprise. They further also play a significant role in generating gainful employment in the rural sector, particularly among the landless, small and marginal farmers and women, besides providing cheap and nutritious food to millions of people. Milk yield is an important economic trait in livestock species. It represents a major source of income in most dairy enterprises.

Economic traits are generally controlled by genetic factors but environmental influences like year, season and age at first calving have significant effects on milk yield. These environmental factors may suppress the animal's true genetic ability and create a bias in the selection of animals. Heritability is required to calculate genetic evaluations to predict response to selection and to help producers decide if it is more efficient to improve traits through management or through selection. Therefore, present study was aimed to evaluate first lactation traits and estimates their genetic parameters in $\mathrm{HF} \times$ Gir half breed cattle.

\section{Materials and Methods}

The data for the present investigation were collected for a period of 40 years (1974-2015) form History sheet of $421 \mathrm{HF} \times$ Gir half breed cows born from 48 sires maintained at Research cum Development Project (RCDP) on cattle, MPKV Rahuri, District-
Ahmednagar (Maharashtra State). Only the sires having records at least 3 daughters were included in the present study. The first lactation length less than 150 days was considered as abnormal and was not included in the analysis. The total duration of the present study was divided into 6 periods. Each year was divided into three seasons namely Rainy $\left(S_{1}\right)$, Winter $\left(S_{2}\right)$ and summer $\left(S_{3}\right)$ various first lactation traits were considered for the study which were age at first calving (AFC). First lactation total milk yield (FLTMY), first lactation 300 days milk yield. (FL300DMY), first lactation length (FLL), First service period (FSP) First Dry period (FDP) and First calving interval (FCI).For accurate estimation of genetic variation present in traits as well as to account for the effect of non-genetic factors, both the genetic and non genetic factors were considered.

\section{Statistical analysis}

The mixed model analysis using least squares maximum likelihood (LSML) program (Harvey, 1990) was used for determining the influence of genetic and non-genetic factors on first lactation production and reproduction traits and estimation of genetic parameters, simultaneously. The model incorporated seasons, period's age at first calving as fixed effects and sires as random effects. The statistical significance of various fixed effects in the least squares model was determined by ' $F$ ' test for significant effects the difference between pairs of levels of effects were tested by Duncan's multiple range test as modified by Kramer (1957). The heritability, genetic and phenotypic correlations were obtained from the above LSML software.

\section{Results and Discussion}

The overall least- squares means and coefficient of variation of productive and reproductive traits are presented in Table 1. 
The overall least-squares mean of FLTMY, FL300days, FLL, FSP, FDP, FCI and AFC were $2701.77 \pm 46.04, \quad 2511.70 \pm 37.40$, $320.43 \pm 3.04, \quad 88.40 \pm 2.58, \quad 130.14 \pm 3.19$, $409.17 \pm 3.25$ and $990.69 \pm 6.53$ respectively.

Effect of season of calving/ birth on first lactation production and reproduction traits

The influence of season of calving was found to be non-significant on all production and reproduction traits of first lactation in $\mathrm{HF} \times$ Gir half breed cattle. The non-significant effect of season of calving on first lactation traits was also reported by many workers (Rashid, 2010; Nehra, 2011 and Divya, 2012) in $\mathrm{KF}$ cattle. Contradictory to the present study significant effect of season of calving of FL300DMY and FLTMY has been documented by Mukherjee (2005) and Rathee (2015) in frieswal cattle.

Effect of period of calving / birth on first lactation production and reproduction traits

Period of calving have a highly significant effect on age at first calving, (AFC), FLTMY and FL 300 days milk yield. Whereas nonsignificant effect on FLL, FSP, FDP and FCI. The lowest AFC were found in period first (Table 1). Higher estimates for FLTMY and FL300 days were found in period first. Similar estimates were reported by Mukherjee (2005), Shelke (2012) and Ambhore (2017) in various crossbreeds. Reproduction traits were not significantly affected by period of calving. These non-significant finding were in accordance with Saha (2001) and Singh and Gurani (2004) in KF cattle.

Effect of sire on first lactation production and reproduction traits

The sire had significant $(\mathrm{P}<0.05)$ effect on AFC, FLTMY and FL300DMY. Similar results were reported by Akhtar et al., (2003) in 5/8 HF $\times 3 / 8 \mathrm{SW}$ cattle, Singh et al., (2014) in frieswal and Divya (2012) in Karan fries cattle.

The non-significant effect of sire was found on FSP, FLL, FDP and FCI. The findings were in consonance with Akhtar et al., (2013) and Ambhore et al., (2017) in 5/8 HF $\times 3 / 8$ SW and Phule Triveni cattle, respectively.

Effect of age at first calving on first lactation production and reproduction traits

The non-significant effect of AFC groups was found on all first lactation production and reproduction traits. This finding was similar to the results reported by Singh (1995), Divya (2012) and Singh (2013) in Karan fries cattle. Whereas significant effect of age groups on FL300 DMY and FLL were reported by Ambhore (2017) in Phule Triveni cattle.

\section{Heritability estimates of production and reproduction traits}

The heritability of AFC, FL300DMY, FLTMY and FDP \& FLL were moderate. Which indicates that these traits were more influenced by additive genetic variability and could be improved by selection and improved management. Whereas, the heritability $\left(\mathrm{h}^{2}\right)$ of FSP, and FCI were very low and associated with high standard error indicating that performance of this trait could be enhanced by improving management and environments factors. The higher heritability of AFC and FL 300 days milk yield in $\mathrm{HF} \times$ Gir half breed cattle. Indicates that selections based on these two traits are more desirable than other traits. The present results were in agreement with the finding reported by Mukherjee (2005) in Frieswal cattle, Nehra (2011) and Dash (2014) in KF cattle and Ambhore (2017) in Phule Triveni cattle. 
Table.1 Least squares means of first lactation reproduction and production traits of $\mathrm{HF} \times$ Gir half bred

\begin{tabular}{|c|c|c|c|c|c|c|c|}
\hline \multirow[t]{2}{*}{ Source of variation } & \multirow[t]{2}{*}{$\mathrm{N}$} & $\begin{array}{c}\text { FSP } \\
\text { (days) }\end{array}$ & FL300DMY (kg) & $\begin{array}{c}\text { FLTMY } \\
(\mathrm{kg})\end{array}$ & $\begin{array}{c}\text { FLL } \\
\text { (days) }\end{array}$ & $\begin{array}{c}\text { FDP } \\
\text { (days) }\end{array}$ & $\begin{array}{c}\text { FCI } \\
\text { (days) }\end{array}$ \\
\hline & & Mean \pm S.E. & Mean \pm S.E. & Mean \pm S.E. & Mean \pm S.E. & Mean \pm S.E. & Mean \pm S.E. \\
\hline Overall mean $(\boldsymbol{\mu})$ & 421 & $130.14 \pm 3.19$ & $2511.70 \pm 37.40$ & $2701.77 \pm 46.04$ & $320.43 \pm 3.04$ & $88.40 \pm 2.58$ & $409.17 \pm 3.25$ \\
\hline \multicolumn{8}{|l|}{ Periods of calving } \\
\hline$P_{1}(1974-1980)$ & 156 & $127.51 \pm 6.22$ & $3238.74 \pm 72^{a}$ & $3388.09 \pm 87^{\mathrm{a}}$ & $319.75 \pm 86.72$ & $86.01 \pm 5.02$ & $405.5 \pm 6.33$ \\
\hline$P_{2}(1981-1987)$ & 61 & $124.88 \pm 7.07$ & $2752.06 \pm 82^{b}$ & $2953.71 \pm 101^{b}$ & $322.98 \pm 7.69$ & $80.19 \pm 5.70$ & $401.37 \pm 7.19$ \\
\hline$P_{3}(1988-1994)$ & 47 & $133.5 \pm 8.00$ & $2350.84 \pm 94^{c}$ & $2539.17 \pm 116^{c}$ & $322.98 \pm 769$ & $88.49 \pm 6.52$ & $413.94 \pm 8.22$ \\
\hline$P_{4}(1995-2000)$ & 77 & $135.77 \pm 6.5$ & $2242.12 \pm 76^{c}$ & $2510.84 \pm 93^{c}$ & $334.46 \pm 6.19$ & $80.51 \pm 5.25$ & $415.93 \pm 6.62$ \\
\hline$P_{5}(2002-2008)$ & 50 & $126.69 \pm 8.02$ & $2188.89 \pm 93^{c}$ & $2334.08 \pm 115^{\mathrm{c}}$ & $320.59 \pm 7.63$ & $86.45 \pm 6.47$ & $407.60 \pm 8.16$ \\
\hline$P_{6}(2009-2015)$ & 30 & $132.51 \pm 10.00$ & $2297.58 \pm 117^{\mathrm{c}}$ & $2484.74 \pm 145^{\mathrm{c}}$ & $305.28 \pm 9.59$ & $108.76 \pm 8.13$ & $410.63 \pm 10.25$ \\
\hline \multicolumn{8}{|l|}{ Season of birth } \\
\hline$S_{1}$ : Rainy & 110 & $126.77 \pm 5.55$ & $2504.98 \pm 64$ & $2680.22 \pm 79$ & $322.92 \pm 5.33$ & $80.83 \pm 4.47$ & $404.8 \pm 5.64$ \\
\hline $\mathbf{S}_{2}$ : Winter & 146 & $127.47 \pm 4.79$ & $2507.35 \pm 56$ & $2672.76 \pm 68$ & $314.03 \pm 4.56$ & $93.43 \pm 3.86$ & $407.3 \pm 4.87$ \\
\hline $\mathbf{S}_{3}:$ Summer & 165 & $136.19 \pm 4.57$ & $2522.79 \pm 53$ & $2752.34 \pm 65$ & $324.35 \pm 4.35$ & $90.94 \pm 3.69$ & $415.40 \pm 4.65$ \\
\hline \multicolumn{8}{|l|}{ Age group } \\
\hline$A_{1}:<905$ days & 232 & $127.78 \pm 5.08$ & $2462.58 \pm 59$ & $2671.02 \pm 73$ & $322.46 \pm 4.83$ & $83.89 \pm 4.10$ & $406.87 \pm 5.57$ \\
\hline$A_{2}: 950-1050$ days & 75 & $136.34 \pm 6.47$ & $2484.84 \pm 75$ & $2682.78 \pm 93$ & $328.70 \pm 6.16$ & $86.08 \pm 5.22$ & $414.15 \pm 6.59$ \\
\hline $\begin{array}{l}A_{3}: 1051 \text { days and } \\
\text { above }\end{array}$ & 114 & $126.31 \pm 5.66$ & $2587.69 \pm 66$ & $2751.53 \pm 81$ & $310.14 \pm 5.39$ & $95.24 \pm 4.57$ & $406.49 \pm 5.76$ \\
\hline
\end{tabular}

Means under each class in the same column with different super scripts differ significantly

Table.2 Estimates of heritability, phenotypic and genetic correlations among first lactation reproduction and production traits

\begin{tabular}{|c|c|c|c|c|c|c|c|}
\hline Traits & AFC & FLL & FSP & FDP & FCI & FL300DMY & FLTMY \\
\hline AFC & $0.20 \pm 0.12$ & $-0.10 \pm 0.42$ & $0.05 \pm 0.08$ & $-0.03 \pm 0.09$ & $0.04 \pm 0.15$ & $0.07 \pm 0.05$ & $0.08 \pm 0.15^{*}$ \\
\hline FLL & $0.06 \pm 0.02$ & $0.11 \pm 0.10$ & $0.65 \pm 0.87$ & $-0.29 \pm 0.56$ & $0.65 \pm 0.46^{*}$ & $0.48 \pm 0.09 * *$ & $0.60 \pm 0.08 * *$ \\
\hline FSP & $0.72 \pm 0.15^{*}$ & $0.20 \pm 0.10$ & $0.02 \pm 0.11$ & $0.70 \pm 0.12$ & $0.93 \pm 0.16^{*}$ & $0.34 \pm 0.03 * *$ & $0.34 \pm 0.03$ \\
\hline FDP & $0.72 \pm 0.18^{*}$ & $0.10 \pm 0.06$ & $0.47 \pm 0.34$ & $0.12 \pm 0.12$ & $0.50 \pm 0.23$ & $-0.06 \pm 0.61 * *$ & $-0.24 \pm 0.02 * *$ \\
\hline FCI & $0.53 \pm 0.35$ & $0.53 \pm 0.11 * *$ & $0.96 \pm 0.56$ & $0.47 \pm 0.45$ & $0.02 \pm 0.11$ & $0.80 \pm 0.09$ & $0.34 \pm 0.02 * *$ \\
\hline FL300DMY & $-0.03 \pm 0.48$ & $0.48 \pm 0.71 * *$ & $0.21 \pm 0.70$ & $-0.26 \pm 0.30$ & $0.22 \pm 0.42$ & $0.19 \pm 0.14$ & $0.87 \pm 0.10 * *$ \\
\hline FLTMY & $-0.27 \pm 0.64$ & $0.69 \pm 0.27$ & $0.42 \pm 0.55$ & $-0.24 \pm 0.06$ & $0.42 \pm 0.65$ & $0.92 \pm 0.05 * *$ & $0.18 \pm 0.10$ \\
\hline
\end{tabular}


Table.3 Analysis of variance of various first lactation reproduction and milk production traits as affected by genetic and non genetic factors

\begin{tabular}{|l|c|c|c|c|c|c|c|}
\hline \multirow{2}{*}{$\begin{array}{l}\text { Source of } \\
\text { variation }\end{array}$} & \multicolumn{7}{|c|}{ Mean sum of squares } \\
\cline { 2 - 8 } & \multicolumn{1}{|c|}{ AFC } & FSP & FL300DMY & FLTMY & FLL & FDP & FCI \\
\hline $\begin{array}{l}\text { Period of birth } \\
\text { for AFC/ } \\
\text { Period of } \\
\text { calving }\end{array}$ & $1112960.18^{* *}$ & 1132.82 & $9931810.45^{* *}$ & $9052380.68^{* *}$ & 4002.76 & 3999.93 & 1754.27 \\
\hline $\begin{array}{l}\text { Season of birth } \\
\text { for AFC/ } \\
\text { Season of } \\
\text { calving }\end{array}$ & 11308.48 & 4084.65 & 13726.15 & 293640.63 & 4540.21 & 5308.51 & 4396.26 \\
\hline $\begin{array}{l}\text { Age at first } \\
\text { calving group }\end{array}$ & - & 2477.48 & 38445.12 & 163159.94 & 7603.45 & 3132.56 & 1573.53 \\
\hline Sire & $19522.01 *$ & 2302.75 & $550409.00 *$ & $834083.86 *$ & 3343.02 & 2029.71 & 2470.59 \\
\hline Error & 27008.67 & 2963.63 & 517003.44 & 711149.98 & 2732.24 & 1929.20 & 3068.27 \\
\hline
\end{tabular}

$* \mathrm{P}<0.05$ and $* * \mathrm{P}<0.01$

Table.4 Least squares means of age at first calving as affected by various factors in $\mathrm{HF} \times$ Gir halfbred

\begin{tabular}{|c|c|c|}
\hline Source of variation & $\mathrm{N}$ & Mean \pm S.E. \\
\hline Overall mean $(\boldsymbol{\mu})$ & 421 & $990.69 \pm 6.53$ \\
\hline \multicolumn{3}{|l|}{ Periods of birth } \\
\hline$P_{1}(1974-1980)$ & 157 & $804.11 \pm 9.52^{c}$ \\
\hline$P_{2}(1981-1987)$ & 61 & $968.18 \pm 15.12^{b}$ \\
\hline$P_{3}(1988-1994)$ & 54 & $974.73 \pm 16.20^{b}$ \\
\hline$P_{4}(1995-2000)$ & 70 & $1080.73 \pm 14.11^{a}$ \\
\hline$P_{5}(2002-2008)$ & 50 & $1080.27 \pm 16.77^{\mathrm{a}}$ \\
\hline$P_{6}(2009-2015)$ & 29 & $1036.13 \pm 22.01^{a}$ \\
\hline \multicolumn{3}{|l|}{ Season of birth } \\
\hline$S_{1}$ : Rainy & 137 & $987.05 \pm 10.82$ \\
\hline $\mathbf{S}_{2}:$ Winter & 157 & $983.84 \pm 10.05$ \\
\hline $\mathrm{S}_{3}:$ Summer & 127 & $1001.18 \pm 10.73$ \\
\hline
\end{tabular}

Means under each class in the same column with different super scripts differ significantly

Genetic and Phenotypic correlations of milk production and reproduction traits

The genetic $\left(r_{g}\right)$ and the Phenotypic $\left(r_{p}\right)$ correlation of first lactation production and reproduction traits are presented in Table 2. The genetic and phenotypic correlations between FLTMY and FL 300 DMY was $0.87 \pm 0.10$ and $0.92 \pm 0.05$ between FLTMY and FLL was $0.60 \pm 0.08$ and $0.69 \pm 0.27$ between FLTMY and FDP was $0.24 \pm 0.02$ and $0.24 \pm 0.06$ between FLTMY and AFC was $0.08 \pm 0.15$ and $0.27 \pm 0.64$ between FLTMY and FCI was $0.34 \pm 0.03$ and $0.42 \pm 0.65$ and 
between FLTMY, FSP was 01.34 \pm 0.02 and $0.42 \pm 0.55$. The positively phenotypic correlation between FLTMY with FLL, FSP and FCI indicated that increase in first lactation FLTMY also tend to increase service period, Lactation length and calving interval (Table 3). However, genetic correlation of FLTMY and FL 300 DMY with FDP was negative and desirable indicating that cows producing more milk have shorter dry period. Similar to the present findings, Mukherjee (2005) also reported higher genetic correlation of FLTMY with FL 300 DMY and FLL in Frieswal cattle and the phenotypic correlation of milk Production with AFC was $0.13 \pm 0.12$ and with FLL it was $0.09 \pm 0.40$ in Karan Fries, cattle Nehra (2011).

\section{Impacts}

The average least squares mean of first lactation were FLTMY $2701.77 \pm 46.04 \mathrm{~kg}$, FL300DMY $2511.70 \pm 37.40 \mathrm{~kg}$, FLL 320.43 \pm 3.04 days, FDP $88.40 \pm 2.58$ days, AFC $990.69 \pm 6.53$ days, FCI $409.17 \pm 3.25$ days and FSP $130.14 \pm 3.16$ days (Table 4 ).

Among the different genetic and non-genetic factors studied, period of calving had significant effect on FLTMY, FL300DMY and AFC and non significant effect on FLL, FDP, FCI and FSP. Season of calving and age at first calving group had non significant effect on all first lactation production and reproduction traits. The sire had significant effect on FLTMY, FL300DMY and AFC and non-significant effect on FLL, FDP, FCI and FSP.

The heritability estimates of FL300DMY, FLTMY, FLL, FDP, AFC, FCI and FSP were $0.19 \pm 0.14,0.18 \pm 0.10,0.11 \pm 0.10,0.12 \pm$ $0.12,0.20 \pm 0.12,0.02 \pm 0.11$ and $0.02 \pm 0.11$, respectively. The heritability of all traits except FCI and FSP from mixed model using LSML was moderate in magnitude which indicated these traits are more influenced by additive genetic variability and hence there is more scope for improvement by selection. The low heritability estimate of FCI and FSP trait indicates that it is influenced more by managemental and environmental factors than by genetic factors.

\section{Acknowledgement}

The authors wish to express their gratitude to the Vice- Chancellor, MPKV, Rahuri for providing necessary facilities for conducting the investigation.

\section{References}

Akhtar, J., Singh, M., Kumar, D and Sharma, K. 2003.Factors affecting economic traits in crossbred cattle. Indian J. Anim. Sci. 73(4): 464-465.

Ambhore, G.S., Singh, A., Deokar, D.K., Gupta, A.K., Singh, M. and VedPrakash. 2017. First lactation production and reproduction performance of Phule Triveni cattle in hot arid region of Maharashtra. Indian J. Anim. Sci. 87(1): 105-108

Dash, S.K., 2014 Genetic evaluation of Karan Fries cattle for fertility and production traits. Ph. D. Thesis, National Dairy Research Institute, Karnal, India.

Divya, P. 2012. Single versus multi-trait models for genetic evaluation of fertility traits in Karan Fries cattle. M.V.Sc. Thesis, National Dairy Research Institute, Karnal, India.

Harvey, W.R. 1990. Guide for LSMLMW, PC-1 Version, mixed model least squares and maximum likelihood computer programme, January 1990. Mimeograph Ohio State Univ., USA.

Kramer, C.V. 1957. Extension of multiple range test to group correlated adjusted mean. Biometric., 13: 13-20.

Mukherjee, S. 2005. Genetic evaluation of 
Frieswal cattle. Ph.D. Thesis, National Dairy Research Institute (Deemed University) Karnal, (India).

Nehra, M. 2011.Genetic analysis of performance trends in Karan Fries cattle. M.V.Sc. Thesis. NDRI (Deemed University) Karnal, India.

RashiaBanu, N. 2010.Genetic evaluation of the lactation curve in Karan Fries cattle. Ph.D. Thesis. NDRI (Deemed University), Karnal, India.

Saha. 2001. Generation wise genetic evaluation of Karan Swiss and Karan Fries cattle. M.Sc. Thesis. NDRI Deemed University, Karnal, India.

Shelke, M.G. 2012. Generation wise persistency of milk production in Phule Triveni Synthetic cows. M. Sc (Agri.) Thesis submitted to MPKV, Rahuri.

Singh, R.K. 2013.Genetic evaluation of Karan Fries sires using multiple trait models. Ph.D thesis submitted to NDRI, Karnal (Haryana).

Singh, M.K. 1995. Factors affecting trend in performance of Karan Swiss and Karan Fries cattle. Ph.D Thesis, NDRI (Deemed University) Karnal, India.

Singh, M.K. and Gurnani, M. 2004. Performance evaluation of Karan Fries and Karan Swiss cattle under closed breeding system. Asian- Australasian J. Anim. Sci., 17(1): 1 - 6.

\section{How to cite this article:}

Jadhav, S.S., D.K. Deokar, Y.G. Fulpagare, U.Y. Bhoite, S.D. Mandkmale and Nimbalker, C.V. 2019. Effect of Genetic and Non-Genetic Factors on First Lactation Production and Reproduction Traits in HF $\times$ Gir Cattle. Int.J.Curr.Microbiol.App.Sci. 8(01): 45-51. doi: https://doi.org/10.20546/ijcmas.2019.801.006 